Portland State University

PDXScholar

\title{
The Influence of Recurrent Modes of Climate Variability on the Occurrence of Monthly Temperature Extremes over South America
}

\author{
Paul C. Loikith \\ Portland State University, ploikith@pdx.edu \\ Judah Detzer \\ Portland State University \\ Carlos R. Mechoso \\ University of California Los Angeles \\ Huikyo Lee \\ California Institute of Technology \\ Armineh Barkhordarian \\ University of California, Los Angeles \\ Follow this and additional works at: https://pdxscholar.library.pdx.edu/geog_fac \\ Part of the Atmospheric Sciences Commons, Climate Commons, and the Environmental Indicators \\ and Impact Assessment Commons \\ Let us know how access to this document benefits you.
}

\begin{abstract}
Citation Details
Loikith, P. C., Detzer, J., Mechoso, C. R., Lee, H., \& Barkhordarian, A. (2017). The influence of recurrent modes of climate variability on the occurrence of monthly temperature extremes over South America. Journal of Geophysical Research: Atmospheres, 122(19).
\end{abstract}

This Article is brought to you for free and open access. It has been accepted for inclusion in Geography Faculty Publications and Presentations by an authorized administrator of PDXScholar. Please contact us if we can make this document more accessible: pdxscholar@pdx.edu. 


\section{Journal of Geophysical Research: Atmospheres}

\author{
RESEARCH ARTICLE \\ 10.1002/2017JD027561 \\ Key Points: \\ - ENSO, PDO, Atlantic Niño, and SAM \\ show significant relationships with \\ extreme temperature months over \\ South America \\ - El Niño-Southern Oscillation is highly \\ influential on the occurrence of \\ extreme temperature months over \\ coastal northwestern South America \\ - Extreme temperature months over \\ many regions of South America are \\ not strongly influenced by major \\ recurrent modes of climate variability
}

Supporting Information:

- Supporting Information S1

- Figure S1

- Figure S2

- Figure S3

- Figure S4

- Figure S5

- Figure 56

- Figure S7

- Figure S8

- Figure S9

- Figure S10

- Figure S11

- Figure S12

- Figure S13

- Figure S14

- Figure S15

Correspondence to:

P. C. Loikith,

ploikith@pdx.edu

Citation:

Loikith, P. C., Detzer, J., Mechoso, C. R., Lee, H., \& Barkhordarian, A. (2017). The influence of recurrent modes of climate variability on the occurrence of monthly temperature extremes over South America. Journal of Geophysical Research: Atmospheres, 122, 10,297-10,311. https://doi.org/10.1002/ 2017JD027561

Received 4 AUG 2017

Accepted 19 SEP 2017

Accepted article online 26 SEP 2017

Published online 14 OCT 2017

C2017. American Geophysical Union. All Rights Reserved.

\section{The Influence of Recurrent Modes of Climate Variability on the Occurrence of Monthly Temperature Extremes Over South America}

\author{
Paul C. Loikith' ${ }^{1}$, Judah Detzer', Carlos R. Mechoso² ${ }^{(D}$, Huikyo Lee ${ }^{3}$ iD, and \\ Armineh Barkhordarian ${ }^{2,3}$ \\ ${ }^{1}$ Department of Geography, Portland State University, Portland, OR, USA, ${ }^{2}$ Department of Atmospheric and Oceanic \\ Sciences, University of California Los Angeles, Los Angeles, CA, USA, ${ }^{3}$ Jet Propulsion Laboratory, California Institute of \\ Technology, Pasadena, CA, USA
}

\begin{abstract}
The associations between extreme temperature months and four prominent modes of recurrent climate variability are examined over South America. Associations are computed as the percent of extreme temperature months concurrent with the upper and lower quartiles of the El Niño-Southern Oscillation (ENSO), the Atlantic Niño, the Pacific Decadal Oscillation (PDO), and the Southern Annular Mode (SAM) index distributions, stratified by season. The relationship is strongest for ENSO, with nearly every extreme temperature month concurrent with the upper or lower quartiles of its distribution in portions of northwestern South America during some seasons. The likelihood of extreme warm temperatures is enhanced over parts of northern South America when the Atlantic Niño index is in the upper quartile, while cold extremes are often association with the lowest quartile. Concurrent precipitation anomalies may contribute to these relations. The PDO shows weak associations during December, January, and February, while in June, July, and August its relationship with extreme warm temperatures closely matches that of ENSO. This may be due to the positive relationship between the PDO and ENSO, rather than the PDO acting as an independent physical mechanism. Over Patagonia, the SAM is highly influential during spring and fall, with warm and cold extremes being associated with positive and negative phases of the SAM, respectively. Composites of sea level pressure anomalies for extreme temperature months over Patagonia suggest an important role of local synoptic scale weather variability in addition to a favorable SAM for the occurrence of these extremes.
\end{abstract}

\section{Introduction}

Temperature extremes are associated with a multitude of severe impacts on society and the environment. Furthermore, temperature extremes are expected change in character across the globe due to anthropogenic warming (Flato et al., 2013), which may result in unprecedented impacts. It is therefore essential to gain a comprehensive understanding of the mechanisms associated with the occurrence of extremes in the current climate so as to best make projections of future events and produce reliable assessments of their impacts. Toward this goal, we present a systematic analysis of the influence that four important recurrent modes of climate variability have on the occurrence of extreme temperature months over South America (SA).

Temperature extremes over SA have received considerably less attention in the literature than those over other regions of the world, even in aspects related to extreme heat (e.g., Horton et al., 2016, and references therein). Furthermore, considering the body of scientific literature on SA climate variability and change, temperature variability has received less attention than precipitation. This imbalance is further exacerbated by the uneven geographical coverage of climate research over SA, which has preferably targeted the southern part of the continent. A detailed review of existing research on temperature extremes over SA is provided by Rusticucci (2012). The present paper contributes to a further understanding of the mechanisms that drive extreme temperatures over the entire SA continent by investigating the influence of key, well-documented recurrent climate modes of atmosphere and ocean variability on monthly temperature extremes. Using gridded data spanning the years 1980-2015, we take a point-wise approach to systematically assessing the level of influence that the El Niño-Southern Oscillation (ENSO), the Pacific Decadal Oscillation (PDO), the Atlantic Niño (ANINO), and the Southern Annular Mode (SAM) have on extremes and examine some related meteorological mechanisms. 
The most influential mode of low-frequency climate variability on the climate of SA at seasonal to interannual time scales is ENSO (Aceituno, 1988; Marengo, 1992; Ropelewski \& Halpert, 1987, 1989). The majority of investigations focusing on the impacts of ENSO on SA climate thus far relate to precipitation (e.g., Cazes-Boezio et al., 2003; Garreaud et al., 2009; Grimm, 2003; Grimm \& Tedeschi, 2009; Haylock et al., 2006; Pisciottano et al., 1994; Poveda et al., 2006), while the relationship between temperature and ENSO, and especially extreme temperatures and ENSO, has received relatively less attention. Garreaud et al. (2009) document a positive relationship between temperature anomalies and ENSO phase over large regions of SA, namely, warm phase events are associated with above average temperatures while cool phase events are associated with below average temperatures. This relationship is strongest along the Pacific Coast and over parts of north-central SA. Using station data, Kenyon and Hegerl (2008) show a significant relationship between ENSO and temperature extremes indices over many stations, especially between warm phase events and extreme warm daytime and nighttime temperatures. Rusticucci and Vargas (2002) document the influence of ENSO on the occurrence and persistence of warm and cold episodes over Argentina. Sea surface temperature (SST) variability in the tropical Atlantic Ocean (i.e., the Atlantic Niño) has also been shown to be associated with climate impacts, especially over northeastern SA through modulation in the position of the Intertropical Convergence Zone (ITCZ; Hastenrath \& Greischar, 1993; Mechoso \& Lyons, 1988; Torralba et al., 2015; Zebiak, 1993).

The PDO, defined on the basis of the dominant pattern of monthly SST variability over the North Pacific on yearly scales (Mantua et al., 1997; Mantua \& Hare, 2002), operates on longer temporal scales of climate variability than ENSO. The PDO is often considered a manifestation of a combination of multiple physical processes operating across a range of spatial and temporal scales (Newman et al., 2016). This mode is generally associated with similar climate influences over SA as ENSO but with roughly half the magnitude of influence (Garreaud et al., 2009). The PDO has been suggested to modulate the impacts of ENSO on precipitation over SA, such that when both modes are in phase their influences tend to reinforce each other while when they are in opposing phase their influence tends to counteract each other (Andreoli \& Kayano, 2005; Kayano \& Andreoli, 2007).

Another climate mode of relevance to the climate of SA is the SAM. Compared with ENSO, the PDO, and the ANINO, the SAM is characterized by a higher frequency and is defined based on anomalies in the atmospheric circulation rather than in SST. An index for this mode is defined as the leading empirical orthogonal function of the sea level pressure (SLP) field or zonally symmetric geopotential height or zonal wind fields south of $20^{\circ} \mathrm{S}$ latitude (Thompson \& Wallace, 2000). Characterized by a north-south seesaw in atmospheric mass between the Antarctic and the Southern Hemisphere midlatitudes, the SAM is generally positively correlated with temperature south of $\sim 40^{\circ}$ latitude accompanied by weaker negative associations in the northern midlatitudes (Garreaud et al., 2009; Gillett et al., 2006).

Individually, these four modes explain a substantial amount of climate variability over SA. However, multiple studies have demonstrated linkages among these modes, their climate impacts, and other modes of atmosphere and ocean variability. The relationship between ENSO and the PDO (Kayano \& Andreoli, 2007) provides one example of the effect of mode interaction on precipitation. The SAM modulates the ENSO signal on precipitation over southeastern SA (Pisciottano et al., 1994; Silvestri \& Vera, 2009), while SST anomalies in the Atlantic Ocean interact with and modulate ENSO impacts over tropical SA (Kayano et al., 2011; Kayano \& Capistrano, 2014). Furthermore, more slowly varying modes may influence the impacts of those with higher frequency such as the documented influence of the sign of the Atlantic Multidecadal Oscillation on the impacts of the ANINO over northeastern SA (Torralba et al., 2015).

In the present paper we identify and physically interpret the associations between large excursions from the mean of these four climate modes and extreme temperature months over SA, under the assumption that the climate influence of these modes is greatest when they are farthest from their mean state. Understanding the physical mechanisms at work for these associations at multiple scales is crucial for interpreting the significance of observed climate trends across SA, future projections of temperature extremes under anthropogenic global warming, and intraseasonal to interannual climate forecasts. Such an understanding can also provide a baseline for evaluating the credibility of climate model simulations over the continent. The need for this information is of increasing importance as temperature extremes are becoming more common over SA (Flato et al., 2013; Vincent et al., 2005) with externally forced warming detectable over some of the continent (de Barros Soares et al., 2016). 


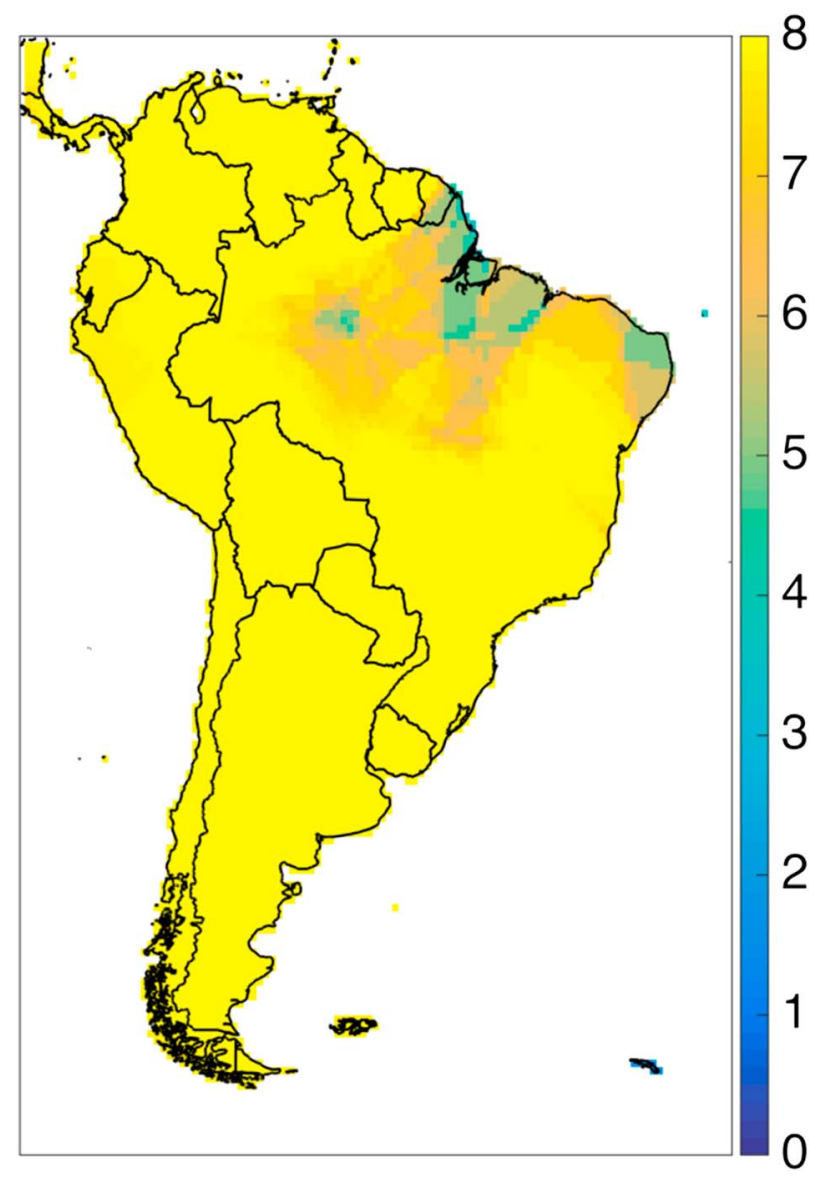

Figure 1. The average number of observation stations contributing to the CRUv4 temperature data at each grid cell over the years 1980-2015. The maximum possible number of stations is eight.
The remainder of the paper is organized as follows. Section 2 describes the data and methodology. Section 3 presents the associations between extreme temperature months and each mode of variability. Section 4 presents a closer look at individual cases and introduces some associated meteorological mechanisms. We conclude in section 5 with a discussion of our findings.

\section{Data and Methodology}

\subsection{Data}

The primary surface temperature data set used is the Climate Research Unit Version 4 (CRUv4) (Harris et al., 2014). CRUv4 is the latest version of the CRU TS data set, which improves on previous versions by employing Angular Distance Weighting for gridding monthly temperature anomalies. Here we use the average surface air temperature product provided monthly on a $0.5^{\circ} \times 0.5^{\circ}$ latitude/longitude grid. Figure 1 shows the average density of stations contributing data to each grid cell over SA for the period of 1980-2015. The majority of grid cells show eight contributing stations, the maximum used in the gridding method; however, station data are not homogeneous in density across SA and many regions have a very sparse observing network. Therefore, toward constraining this uncertainty in our analysis, we also employ three additional gridded surface temperature products, one station based (University of Delaware; Willmott \& Matsuura, 2001) and two reanalysis (ERA-Interim; Dee et al., 2011 and the Modern Era RetrospectiveAnalysis for Research and Applications version 2, MERRA2; Gelaro et al., 2017) data sets, with further information and corresponding figures provided in the supporting information.

Climate indices for ENSO, PDO, and SAM are provided for free via the Web from the U.S. National Oceanic and Atmospheric Administration's Earth System Research Laboratory (http://www.esrl.noaa.gov/psd/data/ climateindices/list/). We utilize the Multivariate Niño Index (MEI) for ENSO. The MEI is a bimonthly index based on six key ENSO-related variables over the tropical Pacific (Wolter \& Timlin, 1998). Because it is a bimonthly index, the January value represents December-January, centered in between the months. Here we only refer to the second of the 2 months in our analysis so that December, January, February MEI values are actually composed of November-December, DecemberJanuary, and January-February bimonthly MEI values. The ANINO index is the area averaged SST anomalies over the region bounded by $5^{\circ}$ and $-5^{\circ}$ north latitude and $-20^{\circ}$ and $0^{\circ}$ west longitude with SST data from the U.S. National Center for Environmental Prediction Reanalysis 1 (Kalnay et al., 1996). SST anomalies are obtained by subtracting the 1980-2015 monthly SST climatology. Sea level pressure (SLP) and precipitation data for section 4 are from MERRA2.

\subsection{Methodology}

All analysis is performed over the years 1980-2015. This time period was chosen as a compromise between having the longest possible record while also having complete overlap (except for University of Delaware data set being 1 year shorter) between all four temperature data sets and climate index records. The period also coincides with some of the highest concentration of station data contributing to the gridded surface temperature products. All anomalies for temperature and atmospheric circulation are computed by removing the monthly 36 year seasonal cycle from each grid point. Seasonal linear trends are removed from the seasonal temperature anomaly time series to reduce the possibility that externally forced transient climate warming would bias the selection of extreme temperature months. Seasons are defined as December, January, February (DJF); March, April, May (MAM); June, July, August (JJA); and September, October, November (SON). Linear trends are removed for each season separately because there is some evidence that the magnitude of historical temperature trends varies seasonally in some regions (de Barros Soares et al., 2016; Rusticucci \& Barrucand, 2004). 

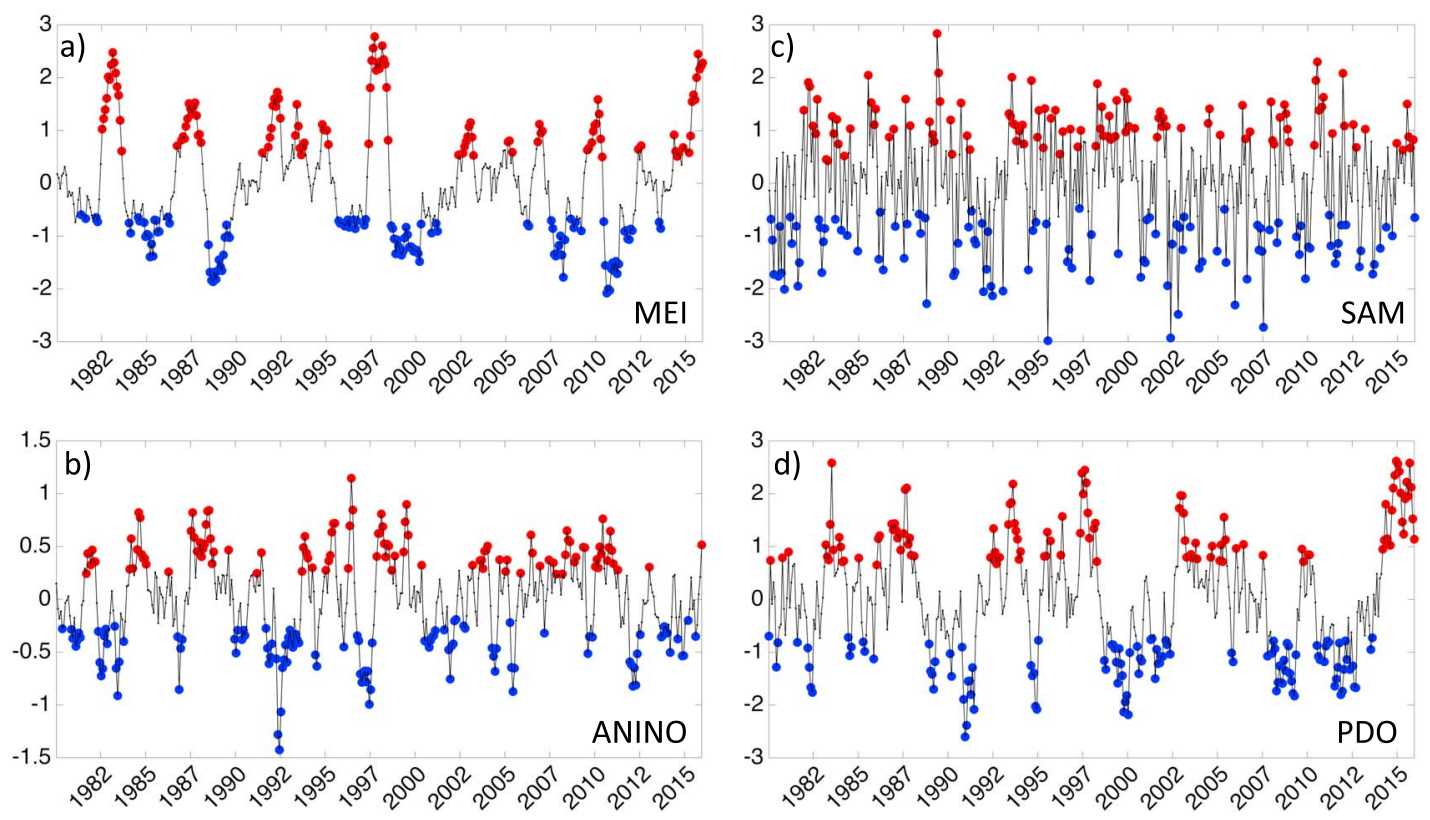

Figure 2. Time series of (a) the MEI, (b) the ANINO, (c) the SAM, and (d) the PDO for the years 1980-2015. Red dots indicate months that are in the upper quartile of the index distribution, while blue dots are months in the lower quartile. The selection of blue and red dots is done separately for each season so that a red dot in July indicates the index is in the upper quartile of the JJA monthly index distribution. Prior to constructing the index time series and identifying upper and lower quartile months, the seasonal time series of each index was linearly detrended.

Association percentages are computed as the percent of extreme temperature months concurrent with months in the top or bottom quartiles of the mode indices, referred to in the text with $a+$ or - , respectively (e.g., ENSO+ refers to months in the top quartile of the MEl distribution). A quartile threshold is chosen for the indices over an absolute threshold (i.e., \pm 1 sigma) so that an equal number of months are used to compute every association percentage even if the index distribution is not symmetrical about zero. Extreme temperature months are defined as those falling above the 90th percentile (T90) and below the 10th percentile (T10) of the monthly temperature anomaly distribution. This results in 11 extreme months per season $(\sim 10 \%$ of 3 months $\times 36$ years). The expected percentage of association occurring by chance is therefore $25 \%$. This is done separately for warm and cold extremes and high and low mode phases. Results are presented by season since the relationship may differ throughout the seasonal cycle. This follows the approach used by Loikith and Broccoli (2014) in analysis of climate variability over North America. As for temperature, linear trends are removed from the seasonal time series for each index prior to computing association percentages.

The statistical significance of the association percentages is determined using a permutation test performed as follows. First, both the temperature and climate index time series are randomly shuffled, keeping seasons intact. Then, the association percentages are computed using the randomly shuffled pairs of data. This procedure is repeated 10,000 times at each grid point. If the observed association percentage falls above the 95th percentile of the synthetic association percentage distribution, then the value at that grid point is deemed significant at the $5 \%$ level (Loikith \& Broccoli, 2014).

\section{Association Between Extreme Temperature Months and Modes}

Figure 2 shows time series of the monthly index values for the four climate modes. The blue and red symbols indicate a month that fell in the lower and upper quartiles of the seasonal index distributions, respectively. The high-frequency variability of the SAM is evident in comparison to the lower-frequency variability of the SST-defined modes. In the following we present and discuss the association percentages between each mode of variability and extreme temperature months. Results for each case (Figures 3-6) are shown only for CRUv4 data; however, stippling in these figures indicates that at least three of the four data sets show statistically significant percentages that are greater than expected by chance. Association maps for the other data sets are shown in Figures S1-S12. Our analysis highlights positive relationships between mode excursions and extreme temperatures such that association percentages are computed for warm and cold extremes 

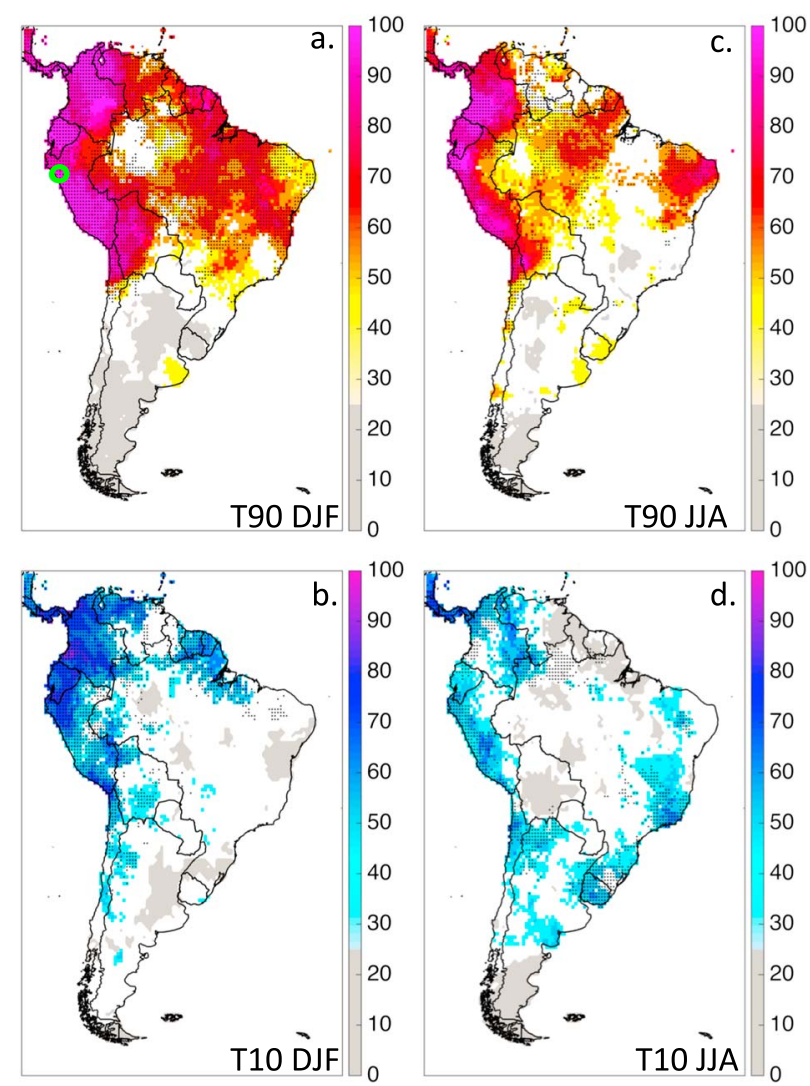

Figure 3. (a) Percent of extreme warm months concurrent with the upper quartile of the MEl distribution during DJF. (b) Percent of extreme cold months concurrent with the lower quartile of the MEl distribution during DJF. (c) Percent of extreme warm months concurrent with the upper quartile of the MEl distribution during JJA. (d) Percent of extreme cold months concurrent with the lower quartile of the MEI distribution during JJA. All results are for CRUv4. Shaded areas indicate where the association percentage is greater than expected by chance $(25 \%)$ and where the result is statistically significant at the $5 \%$ confidence level. Stippling is where at least three of the four reference data sets have statistically significant percentages that are greater than $25 \%$. White areas are where the association percentage is greater than $25 \%$ but not statistically significant. Gray shading indicates association percentages below $25 \%$. Warm color shading corresponds to extreme warm months (T90) and cool color shading to extreme cold months (T10). The green circle over Peru in Figure 3a identifies the grid cell used for the individual cases analysis. concurrent with index values in the upper and lower quartiles, respectively. We find that in most cases these provided the most robust relationships, which justifies our choice of limiting the presentation of our results in this way.

\subsection{ENSO}

The association percentages for ENSO are displayed in Figure 3 for DJF ( $a$ and $b$ ) and JJA ( $c$ and d). The relationship between T90 and ENSO+ in DJF is very high over many portions of the northern half of the continent (Figure 3a). Particularly, high percentages are found along the Pacific Coast stretching from Colombia in the north to northern Chile in the south where values approach $100 \%$ in many cases and data set agreement is strong. This means that nearly every extreme warm December, January, or February between 1980 and 2015 has been concurrent with ENSO+ there. This is largely expected due to the proximity of the region to the anomalously warm Pacific SSTs, which define ENSO + events and act as a source of anomalous convective heating of the overlying atmosphere. High percentages are also found in portions of North Brazil, extending into French Guyana and Surinam, although with less robust data set agreement, and also extending southward into Amazonia. Coastal central Brazil, in the vicinity of the state of Bahia, also shows percentages nearing or exceeding $70 \%$. Extreme warm temperature months are not strongly associated with ENSO+ months in much of the southern two thirds of SA.

DJF T10 months show strong associations with ENSO - in many of the same regions as for T90 with ENSO+ (Figure 3b). For example, high values are found over much of Colombia and Ecuador and portions of Peru and northern Chile. Areas without shading but with stippling, such as over portions of eastern Peru, indicate where the other three data sets show statistically significant values while CRUv4 does not. Therefore, in such regions, CRUv4 is an outlier while the other three data sets produce statistically significant values (see Figures S1-S3). Compared with T90 ENSO+, the magnitude of the association percentages is lower along the Pacific Coast and North Brazil, while there are no significant values across much of the rest of Brazil. This contrast between ENSO+ and ENSO- suggests considerable asymmetry in the effects of ENSO on temperature extremes. This asymmetry in impacts may reflect asymmetry in ENSO phases themselves (Liang et al., 2017).

In JJA (Figure 3c), when ENSO is weaker in the tropical Pacific Ocean, ENSO+ events are still associated with very high percentages along the Pacific Coast of the northern half of SA with good data set agreement. However, the spatial extent and magnitude of the significant values are generally lower throughout the rest of SA compared with DJF with the notable exception of Northeast Brazil, which shows higher values in JJA. This feature coincides with a well-documented ENSO-precipitation relationship, with warm phases associated with drier than average conditions which could lead to anomalously warm temperatures (Ropelewski \& Halpert, 1987). ENSO- T10 associations for JJA (Figure $3 \mathrm{~d}$ ) are the weakest and least spatially coherent of the four cases. The region extending from coastal Peru and northern Chile into northern Argentina exhibits significant values and good data set agreement, as does northwestern Colombia. Some small areas of significance are also found over Uruguay and the southeastern coast of Brazil.

\subsection{ANINO}

Figure 4 shows the association percentages for ANINO months with T90 and T10 for DJF and MAM. These seasons are chosen to capture the documented influence that the ANINO has on the position of the with 

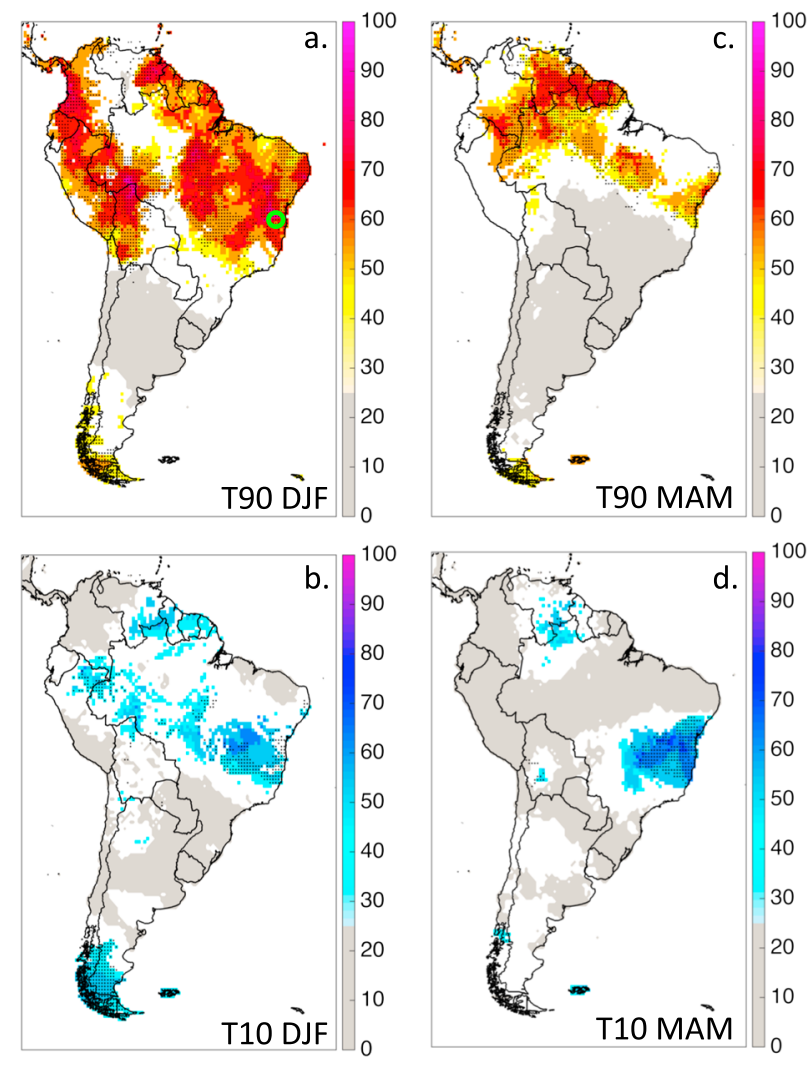

Figure 4. Same as in Figure 3 except for the ANINO and for (left) DJF and (right) MAM. precipitation influences over portions of SA (Torralba et al., 2015). In DJF, the T90 months (Figure 4a) are significantly associated with ANINO+ in a band stretching from southern Bolivia north to the Pacific Coast of Colombia with particularly high values and spatially coherent data set agreement in a region encompassing northern Bolivia and the Brazilian states of Acre, southern Amazonas, and Rondonia. Another region of significant values encompasses much of the South Atlantic Convergence Zone region, from central and eastern Brazil extending along the Atlantic coast northward to eastern Venezuela. This region exhibits data set agreement in some areas, but overall, the lack of stippling suggests caution in interpreting the robustness of the relationship. There is also evidence of relatively weak but significant positive association values over the southern tip of SA. For T10 ANINO - in DJF (Figure 4b), the main areas of significant percentages are in a scattered band stretching from northern Peru southeast to coastal Brazil as well as an area of southern Chile and Argentina. Data set agreement is modest in the northern region but robust in the southern one.

In MAM, T90 (Figure 4c) shows high percentages with good data set agreement over a band stretching from French Guyana westward to Venezuela then southwestward into southern Colombia and northeastern Peru. There is also a less coherent band extending southeastward from this region across Brazil to the Atlantic Coast. T10 ANINO- values (Figure 4d) are mostly significant in a region south of Northeast Brazil. Torralba et al. (2015) document the influence of the ANINO on precipitation over northeastern SA and demonstrate a modulation of the seasonal extent of the during MAM in response to Atlantic SST variability. Our results suggest that temperature anomalies do not present the same behavior as precipitation anomalies in relation to the ANINO in this region.

\subsection{PDO}

Figure 5 shows the association percentages for the PDO. For DJF T90, (Figure 5a), there are few areas of significant association percentages with some small areas broadly scattered across the northern two thirds of SA with even fewer areas exhibit strong data set agreement. For T10 (Figure 5b), high percentages are found over much of Colombia, western Venezuela, and Ecuador with good data set agreement, while the rest of the northern portions of SA show widely scattered patches of significant values. These patches tend to coincide with some of the areas that show association between ENSO- and T10, consistent with the demonstrated positive relationship between the PDO and ENSO (e.g., Moon et al., 2015). However, many regions do not show similar association percentages as for ENSO, such as over Peru in both T90 and T10 cases. This suggests a weak role for the PDO in driving extreme temperature months in DJF in most places, and where this role is stronger according to this analysis, such as in northern SA for T10, the result may be partly a manifestation of the positive relationship between ENSO and the PDO.

In JJA, T90 months (Figure 5c) are strongly associated with PDO+ months over much of the same portion of northwestern SA that exhibits a strong relationship between T90 and ENSO+ (Figure 3c). The similarity among regions of influence indicates that when the PDO is in the upper quartile of its index distribution, ENSO is often also in its upper quartile. This effect is also apparent over a small part of Northeast Brazil; however, the values and data set agreement are weaker for the PDO compared with ENSO. For T10, there are few areas showing statistically significant association with PDO- months in JJA (Figure 5d). This not only indicates asymmetry in the relationship between the PDO and extreme temperatures over portions of SA but also suggests that the close relationship between ENSO and the PDO does not influence extreme cold temperatures over SA in JJA in most regions.

Results for DJF and JJA suggest that the PDO does not strongly influence temperature extremes over SA as an independent mode of climate variability but rather through its relationship with ENSO. Such a suggestion is 

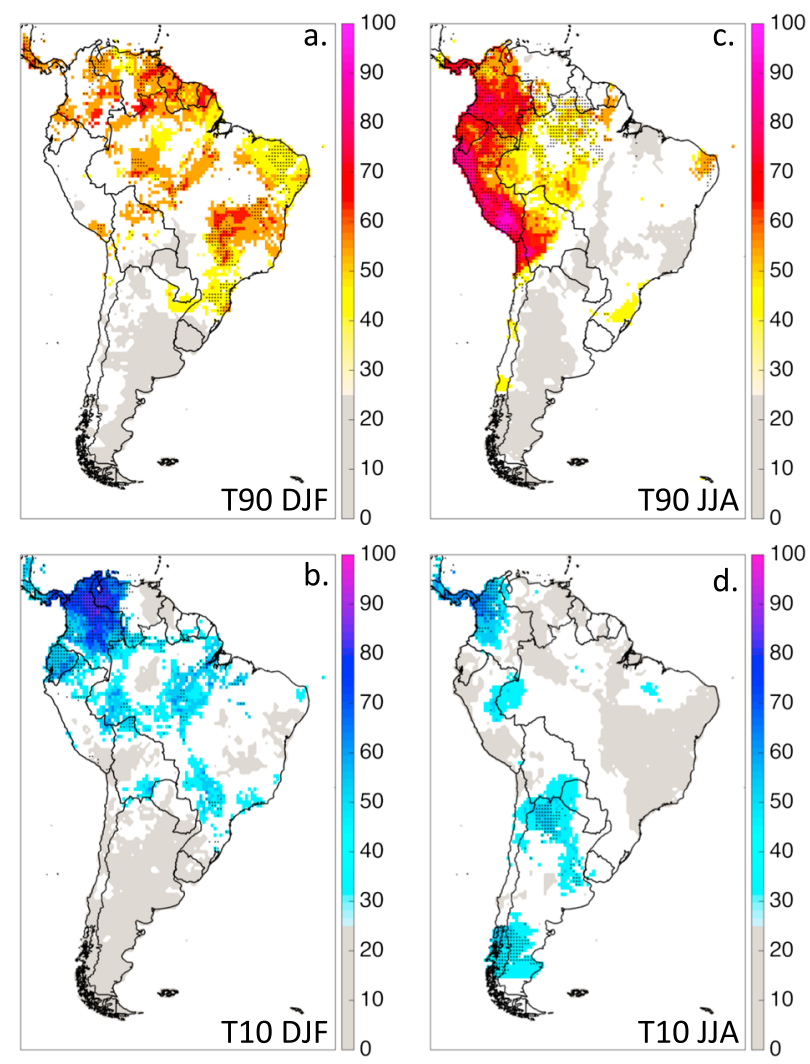

Figure 5. Same as in Figure 3 except for the PDO. broadly consistent with the premise that the PDO results from a combination of different physical processes operating at multiple spatial and temporal scales including a demonstrated relationship with ENSO (Newman et al., 2016, and references therein). In our results, PDO+ and ENSO+ months are coincident about $41 \%$ of the time in DJF and about $56 \%$ of the time in JJA with PDO- and ENSO- months coinciding about $52 \%$ and $33 \%$ of the time in DJF and JJA, respectively. Some studies have proposed a compounding effect of the PDO on ENSO regarding climate impacts, especially in association with precipitation (Andreoli \& Kayano, 2005). In our analysis we do not find evidence of this effect; however, we only investigate the concurrence between extremes and the PDO and ENSO whereas it is possible that the magnitude of an extreme could be enhanced by both modes being in the same phase.

\subsection{SAM}

Association percentage results for the SAM are displayed in Figure 6. The SAM is active year-round; however, Thompson and Wallace (2000) demonstrate that this mode is most active in the late southern spring centered on November. This is also a season in which there is an established relationship between the SAM and ENSO (Fogt \& Bromwich, 2006; Silvestri \& Vera, 2009); however in this study, we limit our statistical focus to the influence of each mode independently. We therefore show results for SON for the SAM but also include results for MAM to compare the SAM-temperature extremes relationship between the two transitions seasons.

Across all panels of Figure 6, there is a robust relationship between extreme temperature months and the SAM over southern SA, with the exception of T90 MAM (Figure 6a). Results for MAM show a high level of asymmetry with greater than $70 \%$ of T10 months being associated with SAM - months over the southern two thirds of Chile and Argentina, while only the very southern tip of SA shows any significant relationship at all for T90 SAM+ months. Data set agreement is also poor for the small T90 area. Additionally, the gray shading in the northern half of Patagonia for T90 MAM indicates that fewer T90 months are associated with SAM+ months than would be expected by chance. There is also some indication of SAM influence on temperature extremes over small regions of the northern half of SA for both T10 and T90 although data set agreement is mostly weak suggesting results could be an artifact of CRUv4 which likely does not have contributions from many local stations in this area.

During SON, the relationship in the vicinity of Patagonia is strong for both tails of the temperature distribution with good data set agreement. Like in MAM (especially T10), the areas of strong percentages align well with expectations from the SAM loading pattern and associated atmospheric dynamics, namely, the weakening of the Antarctic polar vortex and associated northward excursions of cold air during SAM- months and a strengthening of the polar vortex and associated confinement of cold air farther south during SAM+ months. There is an apparent high degree of symmetry for the SAM- temperature extreme relationship at the monthly scale over Patagonia during SON, which contrasts with the weak symmetry found in the MAM results.

\subsection{Extreme Temperatures Without Extreme Indices}

The results presented in the above sections emphasize the influence that highly amplified phases of four key modes of climate variability have on extreme temperature occurrence. However, except for a few cases such as along the coast of Peru in DJF with ENSO+, the link between mode phase and magnitude with extreme temperature is not absolute and sometimes may not be statistically significant. Here we focus on the modes of tropical ocean SST variability (ENSO and ANINO) and highlight where temperature extremes are more likely to occur when neither index is highly amplified. Figure 7 shows the percentage of extreme temperature months that occur when neither ENSO nor ANINO are in their upper or lower quartiles in the CRUv4 data 

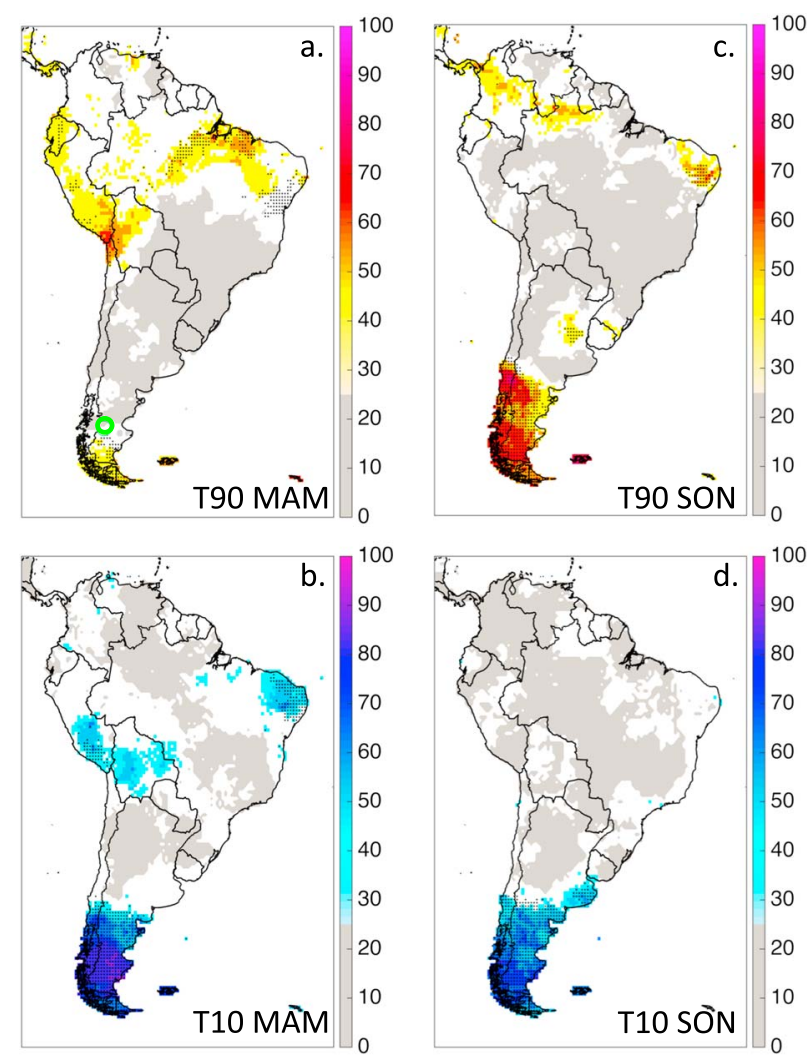

Figure 6. Same as for Figure 3 except for the SAM and (left) MAM and (right) SON. set. Results for the other data sets are displayed in Figures S13-S15. All values are shown regardless of statistical significance to mark where temperature extremes are more or less likely to occur when neither ocean basin exhibits large tropical SST excursions.

The color shading in Figure 7 represents a location where an extreme temperature month is more likely ( $>25 \%$ ) when neither ENSO nor the ANINO is in the top or bottom quartiles of the ENSO and ANINO index distributions. In other words, if a grid cell has a value of $75 \%$, that means that $75 \%$ of extreme temperature months occurred when the values for both the MEI and the ANINO index were between their 25th and 75th percentiles. For T90 in DJF (Figure 7a), a region centered on the Argentina/Paraguay/Brazil border shows greater than expected values, while over most of $S A$ the likelihood of an extreme temperature month when both modes are not highly amplified is small. In MAM (Figure 7b), much of the southern half of SA shows values greater than $25 \%$ with some values reaching as high as $60 \%$. T90 JJA (Figure 7c) shows the largest values over eastern portions of Brazil, while in SON (Figure 7d) Patagonia shows the largest and most spatially coherent values.

For T10 extremes in DJF (Figure 7e), the largest values are found over Northeast Brazil with some greater than expected by chance associations to the west across Brazil stretching toward the Pacific Coast. In MAM (Figure 7f), similar to T90 but confined to more southern latitudes, the most robust association between T10 months and months when neither mode is in an amplified state is over the southern portions of SA. For JJA (Figure 7g), Patagonia and a band extending from Venezuela southeast into central and eastern portions of Brazil is shaded, while a wedge-shaped region extending northward from the Uruguay coast has no extreme cold months when neither mode is not in the upper or lower quartiles. For SON (Figure 7h), the main region of shading is centered over the Argentina/Paraguay/Brazil border, which corresponds to a similar region of shading for T90. However, T90 SON shows strong association percentages over Patagonia while T10 shows low values. This suggests asymmetry in the influence of large excursions from the mean of these modes and impact on extreme temperatures here, with extreme cold months being more influenced by highly anomalous tropical ocean SSTs than extreme warm months.

\section{Individual Case Analysis}

In this section, a brief investigation of the key meteorological drivers of extreme temperature months at three select grid cells is presented. At the locations, represented by a grid cell in the temperature data set and highlighted with a green circle in Figures $3 a, 4 a$, and $6 a$, one or more modes are particularly influential on the occurrence of extreme temperature months and data set agreement is strong. A grid cell located over northwestern Peru is chosen to investigate ENSO and the PDO, one over coastal Bahia in Brazil is chosen for ANINO, and a grid cell over central Patagonia is chosen to investigate the SAM.

\subsection{Statistical Associations}

The scatterplots in Figure 8 show the relationship between monthly temperature and the MEl and the PDO for DJF and JJA at the grid cell over northwestern Peru highlighted in Figure 3a. In DJF (Figure 8a), there is a strong positive relationship between ENSO and monthly temperature anomalies with all T90 months falling above the 75th percentile of the MEl distribution. The relationship at the cold tail is weaker, consistent with Figure 3, with three T10 months occurring when the MEl is between the 25th and 75th percentiles. This highlights the asymmetry between the tails of the temperature distribution with respect to the influence of ENSO; however, it is clear from Figure 8a that colder and warmer months are generally associated with lower and higher MEl values, respectively. The middle of the temperature distribution coincides closely with the middle of the MEI distribution indicating a generally linear relationship between ENSO and temperature in DJF. 


\section{AGU Journal of Geophysical Research: Atmospheres 10.1002/2017JD027561}
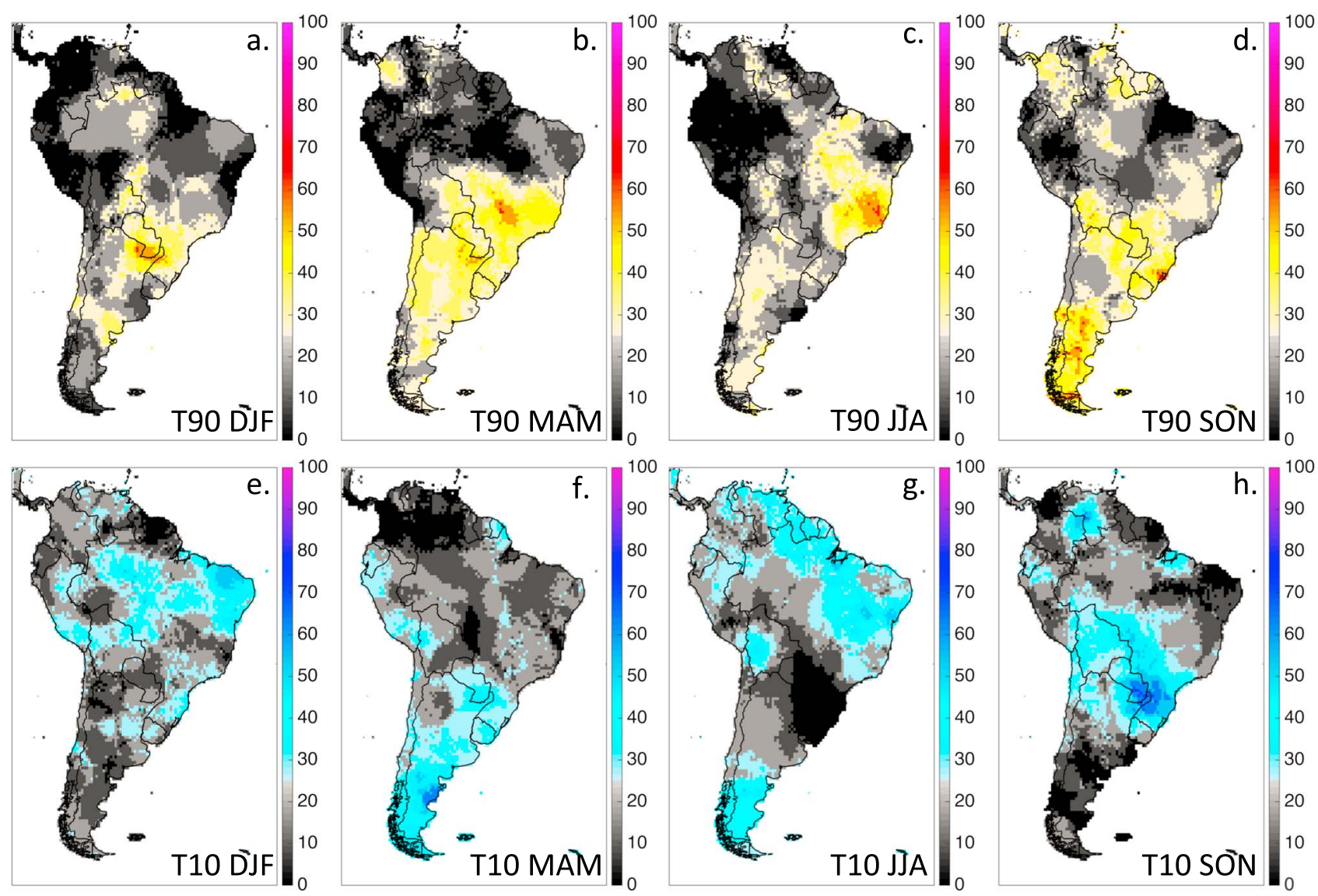

Figure 7. The percent of extreme (top) warm temperature months and (bottom) cold temperature months that occur when neither the MEI nor the ANINO are in the upper or lower quartiles of their index distributions. Color shading indicates where the percent is greater than expected by chance (25\%) while gray areas are where values are less than $25 \%$. Results are presented for each season for T90 and T10 months.

Similar results are found for JJA (Figure 8b), but the relationship for both tails of the distribution is slightly weaker.

In DJF, the PDO does not show a significant association with ENSO for T10 and T90 despite a correlation of 0.44 between its index and the MEl. In Figure $8 c$, the PDO index is scattered against monthly temperature anomalies as for ENSO and for the same grid cell, but blue dots indicate months that were also ENSOand red dots ENSO+ months. Consistent with the already established relationship between ENSO and temperature extremes, the majority of blue (red) dots are generally associated with negative (positive) temperature anomalies. However, while many of the PDO+ months are also ENSO+ months, the warmest and coldest months tend to be concurrent with neutral PDO months. Thus, while ENSO and PDO exhibit some level of positive correlation, this relationship is not strong enough in DJF for the PDO to be clearly associated with extreme temperature months at this grid cell. Furthermore, there is no evidence of the influence on temperature being compounded when the PDO and MEl are in phase, as it has been suggested for precipitation over some parts of SA (Kayano \& Andreoli, 2007). The warmest and coldest months do not tend to be those where the PDO and ENSO are strongly in phase. This does not mean that there is no compounding influence on temperature from the PDO and ENSO over SA in general, but at this grid cell representing a region of strong ENSO influence over the period of 1980-2015 during DJF, there is not evidence of such an effect.

JJA (Figure 8d) results differ from DJF in that there is a strong relationship between the PDO and temperature, especially on the warm side of the temperature distribution. While not all T90 months are associated with PDO+ months, seven out of 11 are. In this case, many of the warmest months are both PDO+ and ENSO+ months suggesting some level of a compounding effect on temperature of the PDO and ENSO being inphase. The relationship is weaker for the cold tail, with many cold extremes occurring apart from PDO- months. 

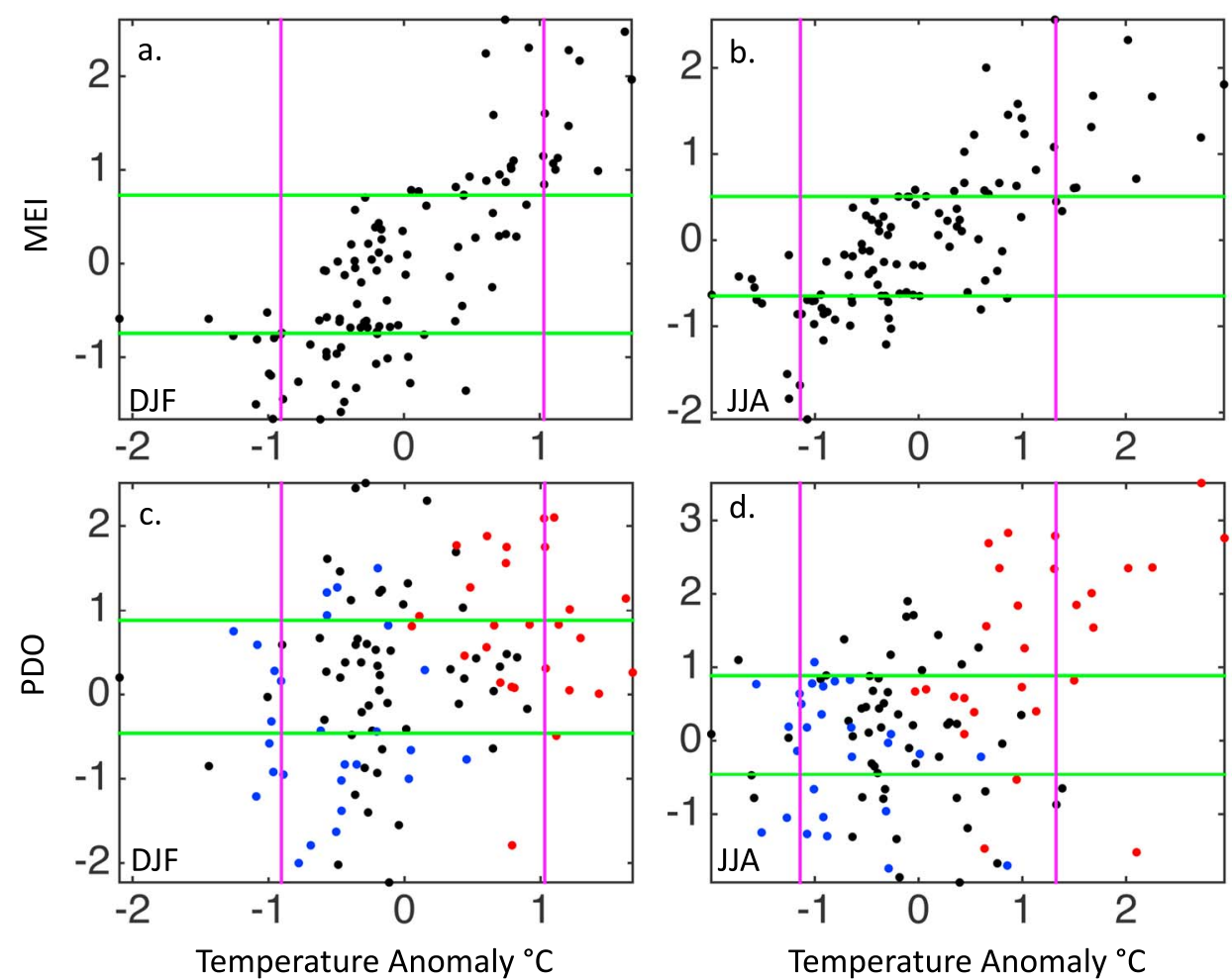

Figure 8. Scatterplots showing the relationship between temperature anomaly and (top) the MEl and (bottom) the PDO at the grid cell over northwestern Peru. Horizontal green lines delineate the upper and lower quartiles of the index distribution, while magenta vertical lines delineate the 10th and 90th percentiles of the temperature anomaly distribution. Results are for (left) DJF and (right) JJA. For the PDO (bottom), blue dots are months where the MEl was in the lower quartile and red dots the upper quartile of the index distribution.

Scatterplots for the grid cell indicated in Figure $4 a$ are shown in Figure 9 to further investigate an area influenced by the ANINO. In Figure 4, this region has the strongest associations between T90 and ANINO + in DJF and T10 and ANINO- in MAM, which is evident in the scatterplots. The entire distribution, however, does not show a strong positive relationship, corresponding to the asymmetry apparent with the weaker association percentages for T10 ANINO- in DJF and T90 ANINO+ in MAM. In DJF, it would be hard to discern a relationship between temperature and ANINO index values if T10 and T90 months were removed. This suggests that the ANINO may be most influential for the occurrence of extreme temperatures. For MAM (Figure 9b), this is also the case, except the strongest relationship is with extreme cold months.

A grid cell in the center of the high association region for the SAM is chosen for the scatterplots in Figure 10 with the grid cell identified in Figure 6a. In MAM, T90 is an outlier with weak association
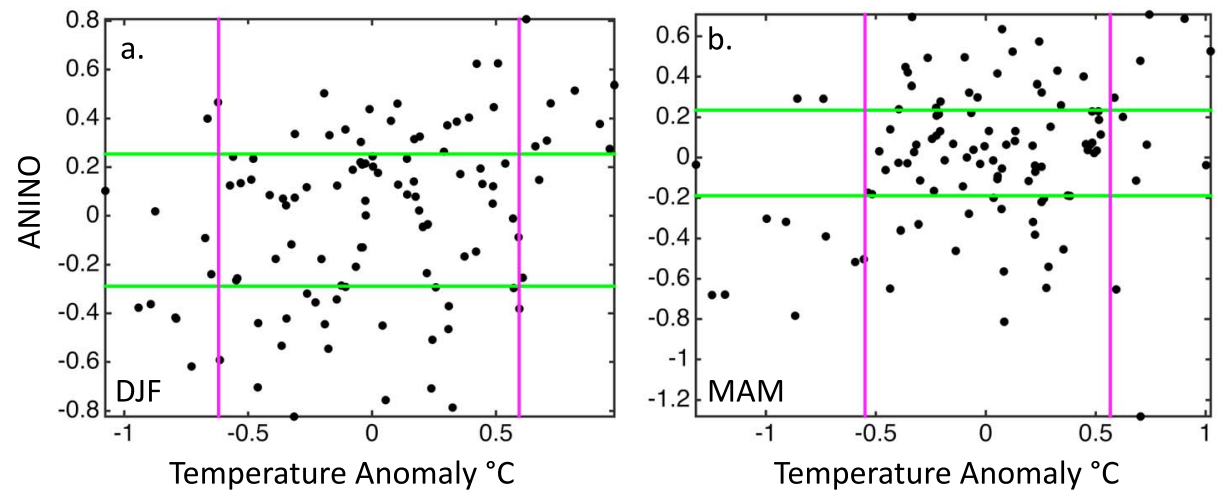

Figure 9. As in Figure 8 except for the ANINO during (left) DJF and (right) MAM at the grid cell over coastal Bahia State. 

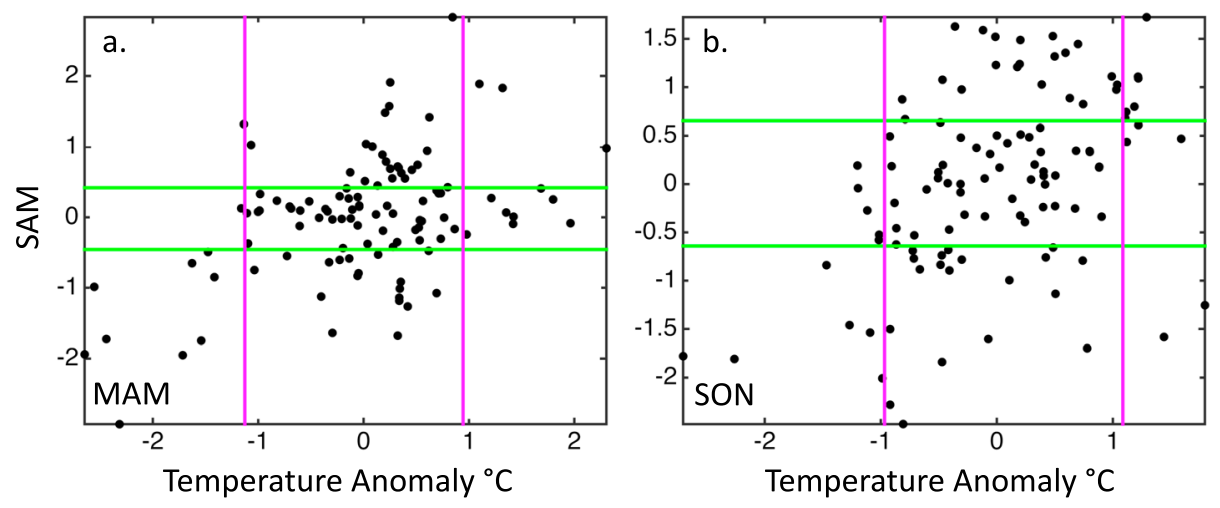

Figure 10. As in Figure 9 except for the SAM during (left) MAM and (right) SON at the Patagonia grid cell.

percentages and even some areas where CRUv4 showed values of less than $25 \%$. This feature, unique to MAM T90, is also supported by the other three data sets (Figures S10-S12), boosting confidence that we are not seeing an artifact of observational uncertainty. The scatterplot in Figure 10a also shows this feature in context to the entire temperature and SAM distributions. The strong association between SAMand T10 months is clear in the scatterplot, but outside of the cold tail the relationship between SAM and temperature becomes weak. In fact, the majority of T90 months coincide with neutral SAM months rather than SAM+, as would be expected in the case of a symmetrical relationship. While the maps for SON in Figure 6 indicate a concise and coherent region of strong influence over southern SA, which also coincides with the region of SA known to be influenced by the SAM (Garreaud et al., 2009), the scatterplot in Figure $10 \mathrm{~b}$ suggests that this relationship is not especially strong.
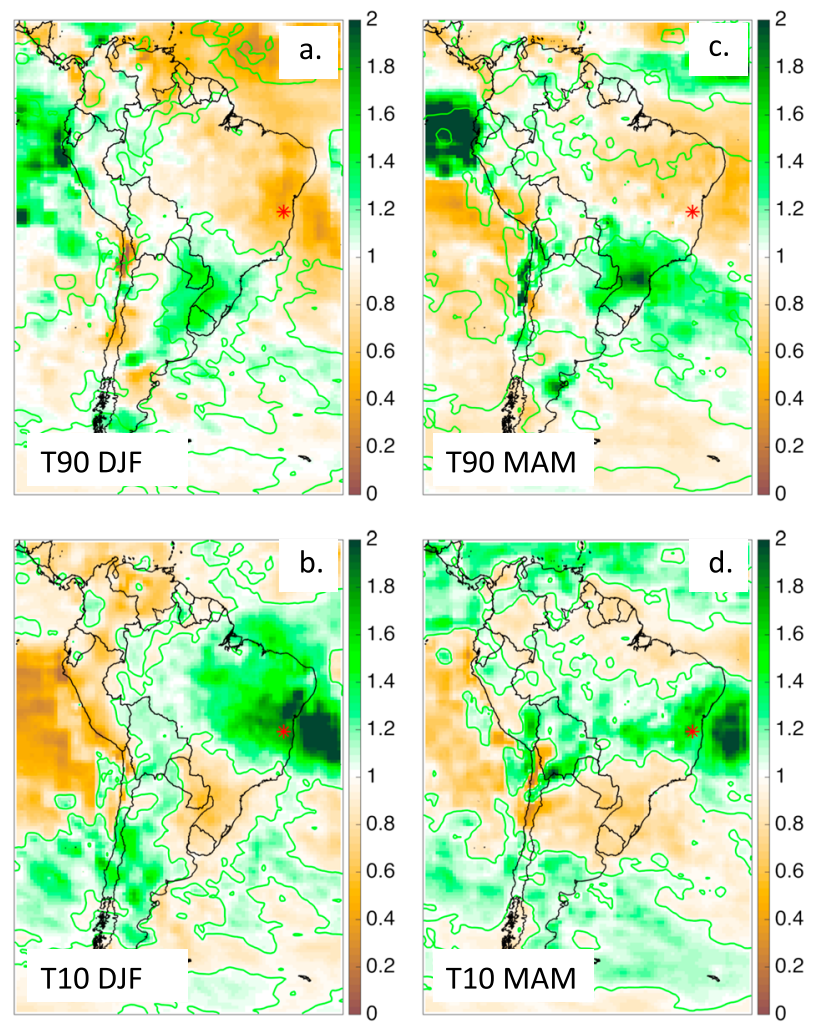

Figure 11. Composites of precipitation anomalies concurrent with extreme temperature months at the grid cell identified with the red star. Anomalies are computed as the fraction of climatology such that a value of one (contoured with green line) would indicate no deviation from average. Results are for (a) T90 DJF, (b) T10 DJF, (c) T90 MAM, and (d) T10 MAM.
There is a significant association between SAM-/T10 and SAM+/T90 months, but the overall relationship does not appear robustly linear. While the SAM is certainly influential, these results indicate that other mechanisms are also important for the occurrence of extreme temperature months over this region.

\subsection{Meteorological Mechanisms}

The statistical relationships established in above sections clearly identify regions where monthly temperature extremes are influenced by large excursions from the mean of the four climate modes. As such, these statistical relationships do not describe the physical way in which the modes influence temperature, nor do they inform on other important mechanisms where association percentages are not $100 \%$. It is therefore also informative to investigate the meteorological mechanisms associated with extreme temperature months. While a more comprehensive investigation of the key drivers of temperature variability and how they may physically relate to climate modes is beyond the scope of our study, here we briefly investigate the drivers of extreme temperatures for the grid cell influenced by the ANINO and the grid cell influenced by the SAM.

The ANINO has been shown to influence precipitation anomalies over northeastern SA, which could in turn influence temperature via a modulation in insolation. To assess whether there is a link between precipitation and extreme temperature months for the ANINO grid cell, Figure 11 shows composites of precipitation anomalies, computed as a fraction of the mean such that a value of one means there is no anomaly, concurrent with T90 and T10 MAM and DJF months. There is a clear relationship between T90 with negative precipitation anomalies and T10 with positive precipitation anomalies. This supports the 

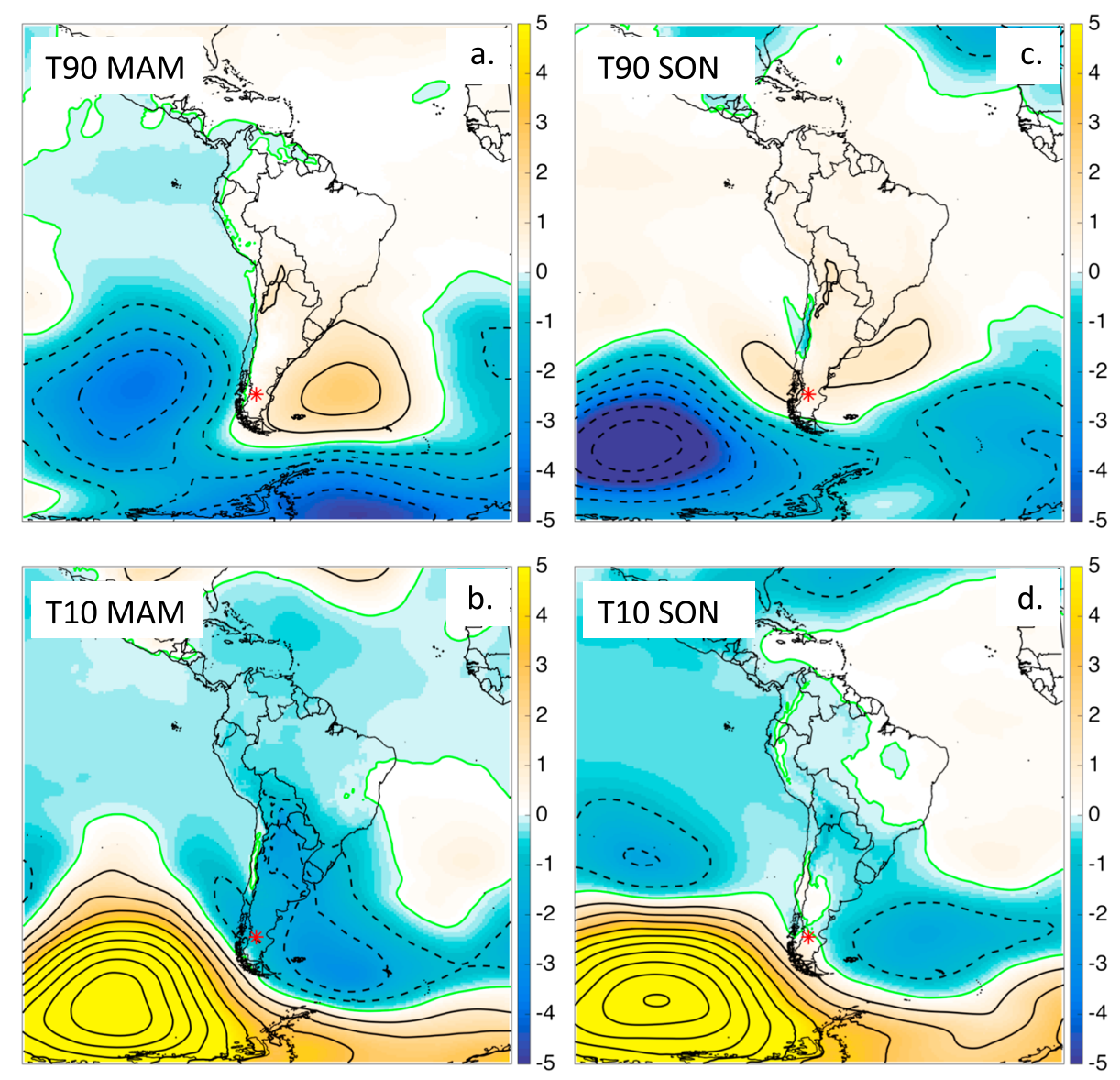

Figure 12. Composites of sea level pressure anomalies in $\mathrm{hPa}$ for extreme temperature months at the grid cell indicated with the red star. The green contour indicates the zero $\mathrm{hPa}$ anomaly line.

conjecture that extreme cold months are influenced by an anomalous reduction in insolation due to clouds, while T90 months are associated with increased solar heating. Positive phases of the ANINO are associated with a southward shift of the ITCZ during the northeastern SA rainy season (Torralba et al., 2015); however, it is not a priori clear that the precipitation anomalies associated with extreme temperatures in Figure 11 result from anomalous excursions of the ITCZ. Another potential pathway is through anomalous $850 \mathrm{hPa}$ winds, which can act to advect high moist static energy from the west to enhance convective precipitation or low moist static energy from the Atlantic Ocean limiting convective precipitation in this region of highprecipitation variability (Ma et al., 2011). We do find that there is some evidence of this effect in the $850 \mathrm{hPa}$ wind field (not shown) in DJF; however, further analysis would have to be conducted to make a robust case for this pathway. It is clear, however, that cold months tend to be associated with wetter than average conditions over the Bahia State of Brazil while warm months are associated with anomalously dry conditions.

The SAM is most influential in the midlatitudes where synoptic scale circulation is key for driving weather and climate variability. As a mode defined by oscillations in atmospheric circulation, it is plausible to expect some influence on temperature to be directly linked to the atmospheric circulation anomalies that define the phase and magnitude of the SAM. However, from the statistical analysis above, it is clear that SAM plays an important but not absolute role in driving temperature extremes over southern SA. Therefore, we can posit that other mechanisms, likely related to synoptic scale circulation and temperature advection, are also important for the occurrence of extreme temperature months here. Figure 12 shows composites of SLP anomalies for extreme temperature months at the Patagonia grid cell as a way to test this hypothesis.

In all four panels of Figure 12, there is an apparent SAM-like feature with the T90 months being associated with a pattern resembling the positive phase of the SAM and T10 months the negative phase. However, 
local-scale circulation anomalies are also evident in all cases. This is most apparent for the MAM T90 case (Figure 12a), where the associated pattern is characterized by a negative SLP anomaly west of the grid cell and a positive anomaly to the east. This configuration would promote advection of warmer air from the north via anomalous low-level circulation. This is also the case where the SAM is least influential of the four cases (Figure 6a). This supports the hypothesis that local-scale synoptic features and low-level temperature advection play a prominent role for the occurrence of extreme warm temperature months here. The pattern for T10 MAM months (Figure 12b) is more suggestive of an annular mode as would be expected if SAM - months were particularly influential; however, a strong positive SLP anomaly to the southwest and a weaker negative SLP anomaly to the northeast also act to promote cold advection from the south. There is some symmetry between the T90 and T10 patterns; however, the anomaly centers are not absolutely collocated nor are they of similar magnitude.

For SON, both composites show an annular structure and little to no local SLP anomaly gradients. This is further indicative of a direct relationship between the displacement of atmospheric mass that characterizes the SAM and its influence on temperature extremes. However, there is a strong SLP anomaly to the southwest of Patagonia (positive anomaly for T10 and negative for T90), which is more synoptic in scale than the more annular SAM pattern. This indicates that both a combination between a favorable phase and amplitude of the SAM and favorable synoptic scale features in the vicinity of southern SA are important to the occurrence of extreme temperatures. The importance of non-SAM dynamics is consistent with findings over Uruguay by Renom et al. (2011). Investigation of additional meteorological variables known or likely to be relevant, such as upper level circulation or SST variability over the South Atlantic and Pacific Oceans (Barrucand et al., 2008; Rusticucci et al., 2003), would present a more complete picture of the mechanisms that drive extremes here; however, such an investigation is beyond the scope of this current study.

\section{Discussion and Conclusions}

We have examined the associations between extreme temperature months and four well-documented recurrent modes of low-frequency atmosphere-ocean climate variability, known to be associated with climate impacts over SA. Of the four modes, three (ENSO, PDO, and ANINO) are defined by anomalies in SSTs while the SAM index is based on atmospheric circulation. The four modes also cover a diverse range of temporal and spatial scales of variability and mechanisms through which they influence climate over SA.

Of the modes analyzed in this study, ENSO is associated with the strongest influence on temperature extremes over SA (Figure 3). Along the coastal zones of northern Chile, Peru, and Colombia, nearly every extreme warm month has occurred when the MEI was in the upper quartile of its distribution. This feature is most robust in DJF when ENSO events are typically most mature. ENSO is also associated with extreme temperature occurrences throughout other portions of northern SA. Atlantic SST variability, defined by the ANINO index, is also associated with extreme temperature months in DJF and MAM (Figure 4) with the strongest influence over the northern half of SA. A preliminary investigation into the meteorological mechanisms associated with extreme temperature months in the area most influenced by the ANINO suggests that extreme cold and warm temperatures are often associated with anomalously wet and dry conditions, respectively (Figure 11). The PDO shows generally weak associations except for T90 in JJA where results are similar to those for ENSO (Figure 5). We do not find strong evidence supporting a compounding effect on the occurrence of temperature extremes of ENSO and the PDO when the two modes are in phase in this analysis. The SAM shows strong association with extreme temperatures over southern SA, except for warm extremes during MAM months (Figure 6). SAM+ (-) months tend to be associated with T90 (T10) months over this region. A combination of a favorable SAM with synoptic scale weather variability appears to play an important role for driving extreme temperatures in southern SA (Figure 12). Substantial asymmetry between the impacts of positive phases on extreme warm temperatures and negative phases on extreme cold temperatures is evident across all four modes.

The present study offers a systematic analysis of the concomitant relationship between highly amplified phases of these four modes of variability, treated as independent phenomena, and extreme temperatures. Several considerations beyond the scope of this current work would lead to productive future research and help gain a more comprehensive understanding of the complex ways in which natural atmosphereocean climate variability influence extreme temperatures over SA. For example, the slow modulation of 
phase for the SST-based modes can cause a lead-lag relationship with temperature lagging changes in the climate indices. Additionally, the relationship between the four indices and climate has been shown to exhibit nonstationarity (Silvestri \& Vera, 2009; Torralba et al., 2015). Therefore, the associations identified in this study may not be the same for different time periods. Coupling between modes or modulation of the impacts of one mode by another may also play important roles in climate impacts (e.g., Andreoli \& Kayano, 2005; Fogt \& Bromwich, 2006; Kayano et al., 2011; Kayano \& Capistrano, 2014). Furthermore, there are likely others modes that have either a direct impact on SA climate or indirect impacts through remote teleconnections or mode impact modulation (e.g., Yeh \& Kirtman, 2005). Examples of these include the slowly varying Atlantic Multidecadal Oscillation (Knight et al., 2005, 2006) and the intraseasonal variability related to the Madden-Julian Oscillation (Naumann \& Vargas, 2010, which can also be modulated by ENSO (Roundy et al., 2010). Lastly, while careful attention is paid to the influence of observational uncertainty, results should still be interpreted with some caution in regions where observational data are limited (Figure 1) and where data sets do not strongly agree.

Beyond statistical associations as explored here, a more comprehensive investigation into the physical mechanisms that lead to extreme temperatures over SA is also warranted. In some cases, as highlighted in Figure 12, mechanisms may be easily linked to recurrent modes of climate variability. In other cases, synoptic scale variability, land-atmosphere interaction, and local-scale phenomena may also play important roles independent of the sign or amplitude of any mode of variability. While some studies have taken this approach to precipitation extremes (Muñoz et al., 2015), to our knowledge this has not been undertaken in a systematic way for temperature extremes. Understanding and characterizing these mechanisms would also provide a valuable target for process-oriented climate mode evaluation and assessment of projected future change in temperature extremes and is the subject of ongoing research.

\section{Acknowledgments}

Support was provided by the U.S. National Science Foundation AGS1547899. The contribution by H.L. to this study was carried out on behalf of the Jet Propulsion Laboratory, California Institute of Technology, under a contract with the National Aeronautics and Space Administration. Climate indices are obtained from the U.S. National Oceanic and Atmospheric

Administration via the Web at https:// www.esrl.noaa.gov/psd/data/climateindices/list/. MERRA2 reanalysis is available from the U.S. National Aeronautics and Space Administration via the Web at https://gmao.gsfc.nasa.gov/reanalysis/MERRA/. Sea surface temperature data for computation of the Atlantic Niño are available via the Web at https://www.esrl.noaa.gov/psd/cgi-bin/ data/timeseries/timeseries1.pl. ERAInterim data are available via the Web at https://www.ecmwf.int/en/research/climate-reanalysis/era-interim. University of Delaware data are available at https:// www.esrl.noaa.gov/psd/data/gridded/ data.UDel_AirT_Precip.html. We thank Silvina Solman and Hans Von Storch for their helpful contribution and guidance on this work.

\section{References}

Aceituno, P. (1988). On the functioning of the Southern Oscillation in the South American Sector. Part I: Surface Climate. Monthly Weather Review, 116, 505-524.

Andreoli, R. V., \& Kayano, M. T. (2005). ENSO-related rainfall anomalies in South American and associated circulation features during warm and cold Pacific Decadal Oscillation regimes. International Journal of Climatology, 25, 2017-2030.

Barrucand, M., Rusticucci, M., \& Vargas, W. (2008). Temperature extremes in the south of South America in relation to Atlantic Ocean surface temperature and Southern Hemisphere circulation. Journal of Geophysical Research, 113, D20111. https://doi.org/10.1029/ 2007JD009026.

Cazes-Boezio, G., Robertson, A. W., \& Mechoso, C. R. (2003). Seasonal dependence of ENSO teleconnections over South America and relationships with precipitation in Uruguay. Journal of Climate, 16, 1159-1176.

de Barros Soares, D., Lee, H., Loikith, P. C., Barkhordarian, A., \& Mechoso, C. R. (2016). Can significant trends in surface temperature and precipitation be detected over South America? International Journal of Climatology. https://doi.org/10.1002/joc.4792

Dee, D. P., Uppala, S. M., Simmons, A. J., Berrisford, P., Poli, P., Kobayashi, S., ... Vitart, F. (2011). The ERA-Interim reanalysis: Configuration and performance of the data assimilation system. Quarterly Journal of the Royal Meteorological Society, 137, $553-597$.

Flato, G., Marotzke, J., Abiodun, B., Braconnot, P., Chou, S. C., Collins, W., ... Rummukainen, M. (2013). Evaluation of climate models. In T. F. Stocker, et al. (Eds.), Climate change 2013: The physical science basis. Contribution of Working Group I to the Fifth Assessment Report of the Intergovernmental Panel on Climate Change (pp. 741-866). Cambridge, UK., and New York: Cambridge University Press.

Fogt, R. L., \& Bromwich, D. H. (2006). Decadal variability of the ENSO teleconnection to the high-latitude South Pacific governed by coupling with the southern annual mode. Journal of Climate, 19, 979-997.

Garreaud, R. D., Vuille, M., Compagnucci, R., \& Marengo, J. (2009). Present-day South American Climate. Palaeogeography, Palaeoclimatology, Palaeoecology, 281, 180-195.

Gelaro, R., McCarty, W., Suárez, M. J., Todling, R., Molod, A., Takacs, L., ... Zhao, B. (2017). The Modern-Era Retrospective Analysis for Research and Applications, Version 2 (MERRA-2). Journal of Climate, 30, 5419-5454.

Gillett, N. P., Kell, T. D., \& Jones, P. D. (2006). Regional climate impacts of the Southern Annular Mode. Geophysical Research Letters, 33 , L23704. https://doi.org/10.1029/2006GL027721

Grimm, A. M. (2003). The El Niño impact on the summer monsoon in Brazil: Regional processes versus remote influences. Journal of Climate, $16,263-280$.

Grimm, A. M., \& Tedeschi, R. G. (2009). ENSO and extreme rainfall events in South America. Journal of Climate, 22, 1589-1609.

Harris, I., Jones, P. D., Osborn, T. J., \& Liter, D. H. (2014). Updated high-resolution grids of monthly climatic observations-The CRU TS3.10 Dataset. International Journal of Climatology, 34, 623-642.

Hastenrath, S., \& Greischar, L. (1993). Circulation mechanisms related to northeast Brazil rainfall anomalies. Journal of Geophysical Research 98, 5093-5102. https://doi.org/10.1029/92JD02646

Haylock, M. R., Peterson, T. C., Alves, L. M., Ambrizzi, T., Anunciação, Y. M. T., Baez, J., ... Vincent, L. A. (2006). Trends in total and extreme South American rainfall in 1960-2000 and links with sea surface temperature. Journal of Climate, 19, 1490-1512.

Horton, R. M., Mankin, J. S., Lesk, C., Coffel, E., \& Raymond, C. (2016). A review of recent advances in research on extreme heat events. Current Climate Change Reports. https://doi.org/10.1007/s40641-016-0042-x

Kalnay, E., Kanamitsu, M., Kistler, R., Collins, W., Deaven, D., Gandin, L., ... Joseph, D. (1996). The NCEP/NCAR 40-year reanalysis project. Bulletin of the American Meteorological Society, 77, 537-471.

Kayano, M. T., \& Andreoli, R. V. (2007). Relations of South American summer rainfall interannual variations with the Pacific Decadal Oscillation. International Journal of Climatology, 27, 531-540. 
Kayano, M. T., Andreoli, R. V., \& De Souza, R. A. F. (2011). Evolving anomalous SST patterns leading to ENSO extremes: Relations between the tropical Pacific and Atlantic Oceans and the influence on the South American rainfall. International Journal of Climatology, 31, 1119-1134. Kayano, M. T., \& Capistrano, V. B. (2014). How the Atlantic Multidecadal Oscillation (AMO) modifies the ENSO influence on the South American rainfall. International Journal of Climatology, 34, 162-178.

Kenyon, J., \& Hegerl, G. C. (2008). Influence of modes of climate variability on global temperature extremes. Journal of Climate, 21, 3872-3889. Knight, J. R., Allen, R. J., Folland, C. K., Vellinga, M., \& Mann, M. E. (2005). A signature of persistent natural thermohaline circulation cycles in observed climate. Geophysical Research Letters, 32, L20708. https://doi.org/10.1029/2005GL024233

Knight, J. R., Folland, C. K., \& Scaife, A. A. (2006). Climate impacts of the Atlantic Multidecadal Oscillation. Geophysical Research Letters, 33, L17706. https://doi.org/10.1029/2006GL02642

Liang, J., Yang, X.-Q., \& Sun, D.-Z. (2017). Factors determining the asymmetry of ENSO. Journal of Climate, 30, $6097-6106$.

Loikith, P. C., \& Broccoli, A. J. (2014). The influence of recurrent modes of climate variability on the occurrence of winter and summer extreme temperatures over North America. Journal of Climate, 27, 1600-1618.

Ma, H.-Y., Ji, X., Neelin, J. D., \& Mechoso, C. R. (2011). Mechanisms for precipitation variability of the eastern Brazil/SACZ convective margin. Journal of Climate, 24, 3445-3456.

Mantua, N. J., \& Hare, S. R. (2002). The Pacific Decadal Oscillation. Journal of Oceanography, 58, 35-44.

Mantua, N. J., Hare, S. R., Zhang, Y., Wallace, J. M., \& Francis, R. C. (1997). A Pacific Interdecadal Climate Oscillation with impacts on Salmon Production. Bulletin of the American Meteorological Society, 78, 1069-1079.

Marengo, J. A. (1992). Interannual variability of surface climate in the Amazon basin. Journal of Climatology. https://doi.org/10.1002/ joc.3370120808

Mechoso, C. R., \& Lyons, S. W. (1988). On the Atmospheric response to SST anomalies associated with the Atlantic warm event during 1984. Journal of Climate, 1, 422-428.

Moon, J. H., Song, Y. T., \& Lee, H. (2015). PDO and ENSO modulations intensified decadal sea level variability in the tropical Pacific. Journal of Geophysical Research, Oceans, 120, 8229-8237. https://doi.org/10.1002/2015JC011139

Muñoz, Á. G., Goddard, L., Robertson, A. W., Kushnir, Y., \& Baethgen, W. (2015). Cross-time scale interactions and rainfall extreme events in southeastern South America for the austral summer. Part I: Potential predictors. Journal of Climate, 28, 7894-7913.

Naumann, G., \& Vargas, W. M. (2010). Joint diagnostic of the surface air temperature in southern South America and the Madden-Julian Oscillation. Weather and Forecasting, 25, 1275-1280.

Newman, M., Alexander, M. A., Ault, T. R., Cobb, K. M., Deser, C., Di Lorenzo, E., ... Smith, C. A. (2016). The Pacific Decadal Oscillation, Revisited. Journal of Climate, 29, 4399-4427.

Pisciottano, G., Díaz, A., Cazes, G., \& Mechoso, C. R. (1994). El Niño-Southern Oscillation impact on rainfall in Uruguay. Journal of Climate, 7 , $1286-1302$.

Poveda, G., Waylen, P. R., \& Pulwarty, R. S. (2006). Annual and inter-annual variability of the present climate in northern South America and southern Mesoamerica. Palaeogeography, Palaeoclimatology, Palaeoecology, 234, 3-27.

Renom, M., Rusticucci, M., \& Barreiro, M. (2011). Multidecadal changes in the relationship between extreme temperature events in Uruguay and the general atmospheric circulation. Climate Dynamics, 37, 2471-2480.

Ropelewski, C. F., \& Halpert, M. S. (1987). Global and regional scale precipitation patterns associated with the El Niño/Southern Oscillation. Monthly Weather Review, 115, 1606-1626.

Ropelewski, C. F., \& Halpert, M. S. (1989). Precipitation patterns associated with the high index phase of the Southern Oscillation. Journal of Climate, 2, 268-284.

Roundy, P. E., MacRitchie, K., Asuma, J., \& Melino, T. (2010). Modulation of the global atmospheric circulation by combined activity in the Madden-Julian Oscillation and the El Niño-Southern Oscillation during boreal winter. Journal of Climate, 23, 4045-4059.

Rusticucci, M. (2012). Observed and simulated variability of extreme temperature events over South America. Atmospheric Research, 106, $1-17$.

Rusticucci, M., \& Barrucand, M. (2004). Observed trends and changes in temperature extremes over Argentina. Journal of Climate, 17, 4099-4107.

Rusticucci, M., \& Vargas, W. (2002). Cold and warm events over Argentina and their relationship with the ENSO phases: Risk evaluation and analysis. International Journal of Climatology, 22, 467-583.

Rusticucci, M., Venegas, S. A., \& Vargas, W. M. (2003). Warm and cold events in Argentina and their relationship with South Atlantic and South Pacific Sea surface temperatures. Journal of Geophysical Research, 108(C11), 3356. https://doi.org/10.1029/2003JC001793

Silvestri, G., \& Vera, C. (2009). Nonstationary Impacts of the Southern Annual Mode on Southern Hemisphere climate. Journal of Climate, 22, 6142-6148.

Thompson, D. W. J., \& Wallace, J. M. (2000). Annular modes in the extratropical circulation. Part I: Month-to-month variability. Journal of Climate, 13, 1000-1016.

Torralba, V., Rodriguez-Fonseca, B., Mohino, E., \& Losada, T. (2015). The non-stationary influence of the Atlantic and Pacific Niños on the North Eastern South American rainfall. Frontiers in Earth Science, 3. https://doi.org/10.3389/feart.2015.00055

Vincent, L. A., Peterson, T. C., Barros, V. R., Marino, M. B., Rusticucci, M., Rusticucci, M., ... Karoly, D. (2005). Observed trends in indices of daily temperature extremes in South America 1960-2000. Journal of Climate, 18, 5011-5023.

Willmott, C. J., \& Matsuura, K. (2001). Terrestrial air temperature and precipitation: Monthly and annual time series (1950-1999). Retrieved from http://climate.geog.udel.edu/ climate/html_pages/README.ghcn_ts2.html

Wolter, K., \& Timlin, M. S. (1998). Measuring the strength of ENSO events: How does 1997/1998 rank? Weather, 53, 315-324.

Yeh, S.-W., \& Kirtman, B. P. (2005). Pacific decadal variability and decadal ENSO amplitude modulation. Geophysical Research Letters, 32, L067503. https://doi.org/10.1029/2004GL021731

Zebiak, S. E. (1993). Air-Sea interaction in the equatorial Atlantic region. Journal of Climate, 6, 1567-1586. 